\title{
Magnitude and Direction of Groundwater Seepage Velocity in Different Soil and Rock Materials
}

\author{
Twana 0. Abdullah1,2, Salahalddin S. Ali ${ }^{3,4}$, Nadhir A. Al-Ansari2, Sven Knutsson'2, Jan Laue² \\ ${ }^{1}$ Groundwater Directorate of Sulaimani, Sulaimani, Iraq \\ ${ }^{2}$ Department of Civil, Environmental and Natural Resources and Engineering, Division of Mining and Geotechnical Engineering, \\ Lulea University of Technology, Lulea, Sweden \\ ${ }^{3}$ Department of Geology, University of Sulaimani, Sulaimani, Iraq \\ ${ }^{4}$ Komar University of Science and Technology, Sulaimani, Iraq \\ Email: twana.abdullah@ltu.se, twanaalandy@yahoo.co.uk, salahalddin.ali@univsul.edu.iq, slah.saeed@komar.edu.iq, \\ *Nadhir.alansari@ltu.se, Sven.Knutsson@ltu.se, jan.laue@ltu.se
}

How to cite this paper: Abdullah, T.O., Ali, S.S., Al-Ansari, N.A., Knutsson, S. and Laue, J. (2020) Magnitude and Direction of Groundwater Seepage Velocity in Different Soil and Rock Materials. Engineering, 12, 242-253.

https://doi.org/10.4236/eng.2020.124020

Received: March 15, 2020

Accepted: April 20, 2020

Published: April 23, 2020

Copyright $\odot 2020$ by author(s) and Scientific Research Publishing Inc. This work is licensed under the Creative Commons Attribution International License (CC BY 4.0).

http://creativecommons.org/licenses/by/4.0/

\begin{abstract}
To understand and anticipate flow in various groundwater media, the magnitude and direction of groundwater flow velocity must be deemed. The studied area which is called Halabja-Sadiq Basin is in the northeastern part of Iraq and covers an area of approximately 128,000 square hectometers. There are several groundwater aquifers in this region that supply nearly over $90 \%$ of all water needs. Subsequently, it is of highly requirement to identify various groundwater behaviors in the area. The objective of this study is to estimate the magnitude and direction of the groundwater seepage velocity with the aid of groundwater tool in Geographic Information System technology. Refer to the results of this analysis, the magnitude value of groundwater flow velocity ranged from 0 to $51 \mathrm{~m} / \mathrm{d}$, whilst the general flow movement is from the eastern part to the western part of the study area. The factor governing the direction of flow and velocity magnitude indicates the direction of dipping of the geological formation strata, the high head of groundwater in the eastern part, and the low transmissivity properties of aquifer materials in the western part.
\end{abstract}

\section{Keywords}

Seepage Velocity, Magnitude, Aquifer, Groundwater, Halabja Saidsadiq Basin

\section{Introduction}

Groundwater is classified as one of the most essential sources that provide the 
main water needs in the Halabja Saida Basin (HSB). Knowing the movement of the groundwater helps us in various important issues including monitoring the adequate amount of groundwater and dispersing the subsurface contaminants.

The Seepage flow describes the permeability of the aquifer to allow water to pass through it [1]. The unsaturated subsurface layer is filled with fluid and then attractively moves to the bottom layer. Accordingly, the subsurface media must be permeable to prevent seepage water to be stored [1]. To estimate the flow velocity field, it can refer to the Darcy law. The groundwater seepage flow field is a vector of seepage flow of the fluid, in which given by two rasters, namely flow direction and magnitude rate [2]. Therefore, procedure of modeling groundwater seepage flow starting with estimating flow direction and flow seep magnitude rate at each point in the flow pass of the aquifer media. Consequently, the key aim of this study is to apply the groundwater tool in Geographic Information System (GIS) technology to calculate and map the speed of groundwater seepage in terms of magnitude rate and direction. This map can be useful to prevent the pollutant disperse in the direction of groundwater flow and to know the potential location of groundwater resources quantitatively. This study converts data and knowledge related to groundwater systems into information, such as the level of groundwater, transmissivity properties, porosity and the thickness of saturation, which can be easily understood by groundwater executives. The GIS technique illustrates a method for calculating the speed of groundwater in terms of magnitude and direction, and this is the first application of this method in the region to create a complete system of groundwater flow that can be applied everywhere in the world.

The problem of characterizing regional one-dimensional flow based on measurements from an observation borehole without pumping has been studied extensively [3] [4]. Methods to estimate the natural horizontal Darcy flux in the aquifer based on borehole observations can be classified in two groups: flux-based methods (e.g., dilution tests, Permeable Flux Meters) and in-hole velocity methods (e.g., Colloidal Borescope, Heat Pulse Flowmeter, Acoustic Doppler Flowmeter, In-Well Point Velocity Probe). These methods are by their nature limited to providing water fluxes or velocities inside the borehole which must subsequently be transformed to regional Darcy flux in the aquifer. While the novelty of this study is applying both observation borehole with pumping and further hydrogeological characteristics from achieved and field survey data with the aid of GIS, to figure out the seepage velocity behavior in the region.

\section{Study Area}

The HSB is positioned in the northeastern part of Iraq, and the value of geographical coordinates ranges between latitudes $35^{\circ} 00^{\prime} 00^{\prime \prime}$ and $35^{\circ} 36^{\prime} 00^{\prime \prime}$ to the north, longitude $46^{\circ} 36^{\prime} 00^{\prime \prime}$ and $46^{\circ} 12^{\prime} 00^{\prime \prime}$ to the east (Figure 1 ). The studied area divided into two sub-basins based on surface water flow contributes in the catchment, including Halabja-Khurmal and Said Sadiq sub-basins [5]. The area is 


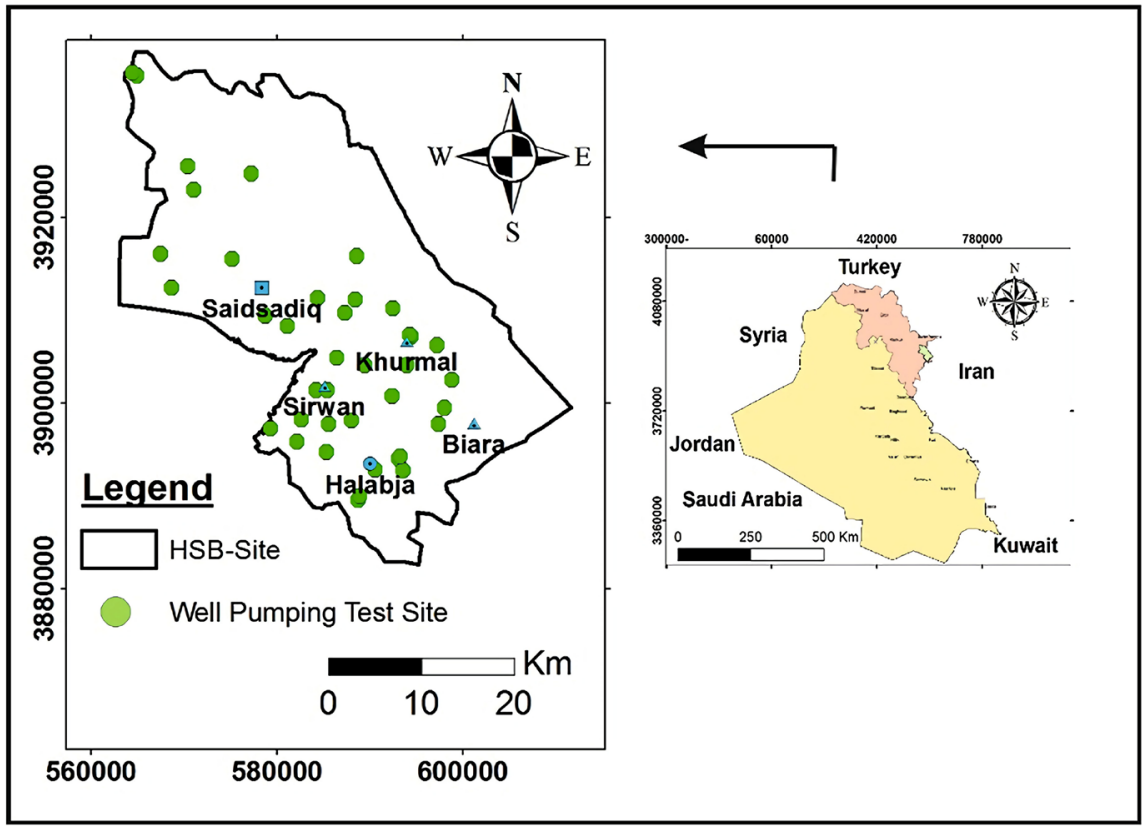

Figure 1. Site map of the HSB [5].

covered around 128,000 square hectometer, with a population of over 200,000 in 2015 [6]. The studied area is characterized by a distinct continental interior climate, nearly $45^{\circ} \mathrm{C}-50^{\circ} \mathrm{C}$ in the summer and about $0^{\circ} \mathrm{C}-10^{\circ} \mathrm{C}$ in the winter, and it has a Mediterranean weather type, with total annual precipitation ranging between 500 and $700 \mathrm{~mm}$.

Different type of geological formations was deposited in the region with different geological time scale, ranging from Jurassic to recent (Figure 2, Table 1). Sarki and Sehkanian Formations of Jurassic age are the oldest outcropped rocks in the basin [5]. The lower and middle Jurassic age rocks are deposited as well in the region including Naokelekan (bituminous limestone), Barsarin (limestone and dolomitic limestone), Sargalu Formations [7]. The Qulqula Group divided into two different types in terms of rock compositions, including the Qulqula Conglomerate Formation and the Qulqula Radiolarian Formation. The outcrops of Kometan Formation (Upper Cretaceous limestone rocks) and Balambo Formation (Lower Cretaceous limestone rocks) are pervasive in the region. In addition, Tanjero and Shiranish Formations (Campanian age) are also outcropped in the basin with occasional outcrops area.

Quaternary deposits are the highly noteworthy unit in the studied area in terms of groundwater resources capability. These deposits as stated by [9], are accumulated as debris flows on the quietly sloping plains or as channel margin sediments and over bank deposits or as path of sediments. The thickness of Quaternary deposits recorded as nearly $300 \mathrm{~m}$ thick from drilling well logs during the field survey period of this project.

Hydrogeological characteristics and aquifer behaviors have been controlled by geological conditions and tectonic processes in the studied basin that influence groundwater movement, occurrence, and water level. Several types of aquifers 


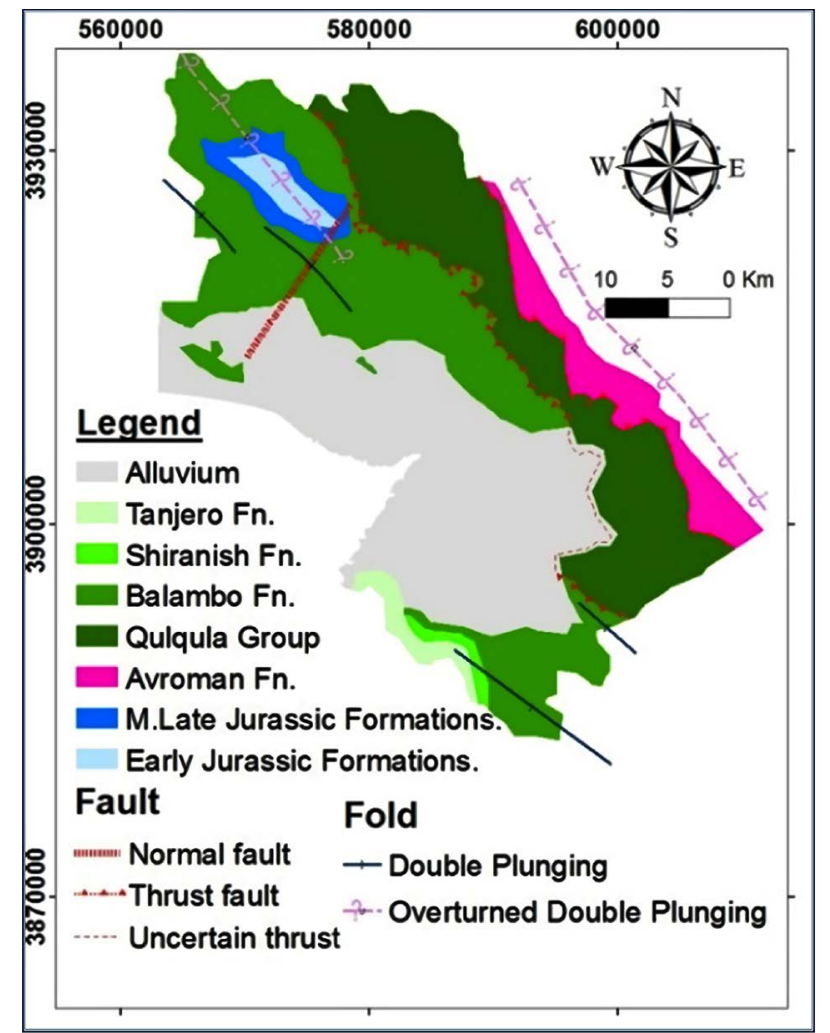

Figure 2. Geological map of the HSB, modified from [5] [8].

Table 1. Aquifer in the HSB.

\begin{tabular}{|c|c|c|c|}
\hline Aquifer & Formation & Thickness (m) & References \\
\hline Intergranular Aquifer (AIA) & Quaternary deposits & more than 300 & [7] \\
\hline Fissured Aquifer (CFA) & $\begin{array}{l}\text { Balambo } \\
\text { Kometan }\end{array}$ & 250 & {$[8]$} \\
\hline Fissured-Karstic Aquifer (CKFA) & $\begin{array}{l}\text { Avroman } \\
\text { Jurassic formation }\end{array}$ & $\begin{array}{l}200 \\
\text { From } 80 \text { to } 200\end{array}$ & {$[9]$} \\
\hline Karstic-Aquifer (TKA) and (JKA) & $\begin{array}{l}\text { Avroman } \\
\text { Jurassic }\end{array}$ & $\begin{array}{c}200 \\
80-200\end{array}$ & [9] \\
\hline $\begin{array}{c}\text { Non-Aquifer (Aquiclude, Aquitard } \\
\text { and TAT) }\end{array}$ & $\begin{array}{c}\text { Qulqula } \\
\text { Shiranish } \\
\text { Tanjero }\end{array}$ & $\begin{array}{c}\text { more than } 500 \\
225 \\
2000\end{array}$ & {$[10]$} \\
\hline
\end{tabular}

are present in the study basin (Figure 3). All aquifer types and thickness are explained in (Table 1). Water table in the mountain series which surround the basin in the northeast and southeast are characterized by deep water level, while the center and the southeastern parts have a shallow water level. The groundwater movement is usually from north and northeastern to the southwest and from south and southeast to the southwest.

The Behavior of groundwater aquifers and hydrogeological characteristics of geological formations are controlled by the condition of sedimentary environment, tectonic process and rate of depositions in the region, which define the 


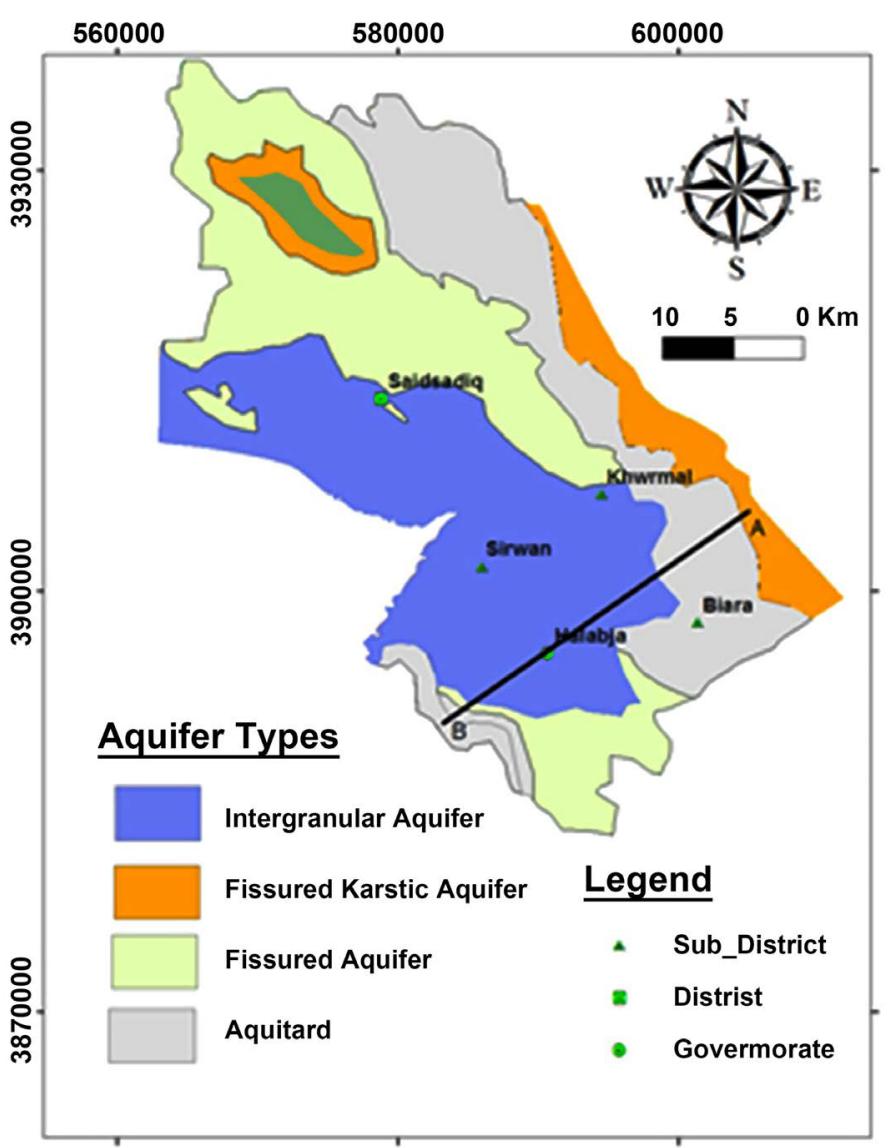

Figure 3. Hydrogeological map of the HSB, modified from [7] [8].

groundwater flow movement, its occurrence, and water head elevations. Several types of hydrogeological aquifers were deposited in the region (Figure 3 and Table 1). Groundwater level in the in the northeast and southeast parts of HSB (mountains area) is characterized by a deep-water level, whilst it has a shallow water level in the center and southeast parts.

\section{Materials and Methods}

Seepage velocity is the velocity of the fluid in the porous media. To calculate the seepage velocity the following equation can be apply [2]:

$$
V=q / n
$$

where $V$ is the seepage velocity in ( $\mathrm{m} /$ day), $q$ is the Darcy's velocity in $(\mathrm{m} /$ day) and $\mathrm{n}$ is the effective porosity [2].

Darcy's Law states that the Darcy velocity q in a porous medium is calculated from the head gradient (the change in head per unit length in the direction of flow in an isotropic aquifer) and hydraulic conductivity $K$ [2] as:

$$
v=-k(\mathrm{~d} h / \mathrm{d} l)
$$

where: $v$ is the Darcy Velocity, $k$ is the hydraulic conductivity $(\mathrm{m} / \mathrm{d}), \mathrm{d} h / \mathrm{d} l$ is the hydraulic gradient (the change in the hydraulic head per unit length in the di- 
rection of the flow in an isotopic aquifer), the negative sign indicates that the flow of water is in the direction of decreasing head. Where $K$ can be calculated from the transmissivity $T$ and thickness b as $K=T / b$.

As groundwater aspects and modeling became an important. However, this task is extremely time consuming when the modeler is required to analyze complex heterogeneous aquifers and manipulate large amounts of input and output data. The GIS technology provides suitable alternatives for efficient management of large and complex databases. GIS is a powerful tool and has great promise for use in hydrogeological problem solving. Most hydrogeological problems have an obvious spatial dimension and spatially distributed models can interact with GIS. GIS has been found to be very effective to assess the groundwater property. GIS are designed to manage, analyze and display all types of spatial data. It provides a visualization platform in which layered, spatially distributed databases can be manipulated with ease. This capability makes GIS a powerful tool in conducting groundwater modeling. The application of traditional data processing methods for groundwater modeling is very difficult and time consuming, because the data is massive and usually needs to be integrated. GIS is capable of developing information in different thematic layers and integrating them with enough accuracy and within a short period of time.

The Darcy Flow function calculates the groundwater volume balance residual, flow direction, and magnitude grids. The tool assumes a steady state flow within the modeled aquifer. The inputs for the tool are a set of rasters (all rasters must have the same extent and cell size), including groundwater elevation head, effective formation porosity, aquifer saturated thickness and aquifer transmissivity.

The groundwater elevation heads, and the aquifer saturated thickness were interpolated from a set of the wells using Inverse Distance Weight (IDW). Transmissivity of the aquifer calculated from pumping well test analysis using AQTESOLV for Windows software and then interpolated using interpolation tool. Porosity of each aquifer estimated from [1], as explained in the (Table 2). The Darcy Flow command in the Groundwater toolbar applied to generate the direction and magnitude of seepage velocity.

\section{Results and Discussion}

Darcy velocity map for the HSB was generated with the aid of groundwater command in spatial analysis tool in GIS/ArcMap software 10.3 using IDW method

Table 2. Representative value of porosity, after [1].

\begin{tabular}{cc}
\hline Aquifer materials & Porosity in percent \\
\hline Dolomitic Limestone & 26 \\
Limestone & $>26-30$ \\
Mixture of clay, sand and gravel & $>30-34$ \\
Sandstone and marly limestone & $>34-37$ \\
\hline
\end{tabular}


for interpolation. From the groundwater head elevation above sea level in meter (Figure 4), the water table shallowest towards the southwestern part of the HSB. This means that the ground water is flowing from the northeastern towards southwestern. The study area is characterized by different groundwater aquifers of different lithological materials, the effective porosity of these materials which were estimated from recommended representative porosity table by Morris and Johnson [1]. Figure 5 shows the effective porosity with the HSB which is ranged between $(26 \%-37 \%)$. The materials of alluvial deposits characterized by higher percentage of porosity compared to the geological formation that consisting of massive rocks.

Saturated thicknesses of each formation in the HSB have been interpolated on Figure 6. The figure illustrated that the saturated thickness scattered in the area randomly, but in general the saturated thickness decreased toward the north eastern part, this is referring to the depth to water table which is deeper in the north eastern part. Figure 7 illustrates the transmissivity of groundwater aquifers in the HSB in $\left(\mathrm{m}^{2} /\right.$ day). The transmissivity in the area decreased toward the southwestern part and it ranges $(0.28-2431) \mathrm{m}^{2} / \mathrm{d}$. Because non-carbonate rock materials exist in the southwestern part of the studied area compared to the northeastern and eastern parts, in which consists of highly fractured and highly jointed carbonate rocks.

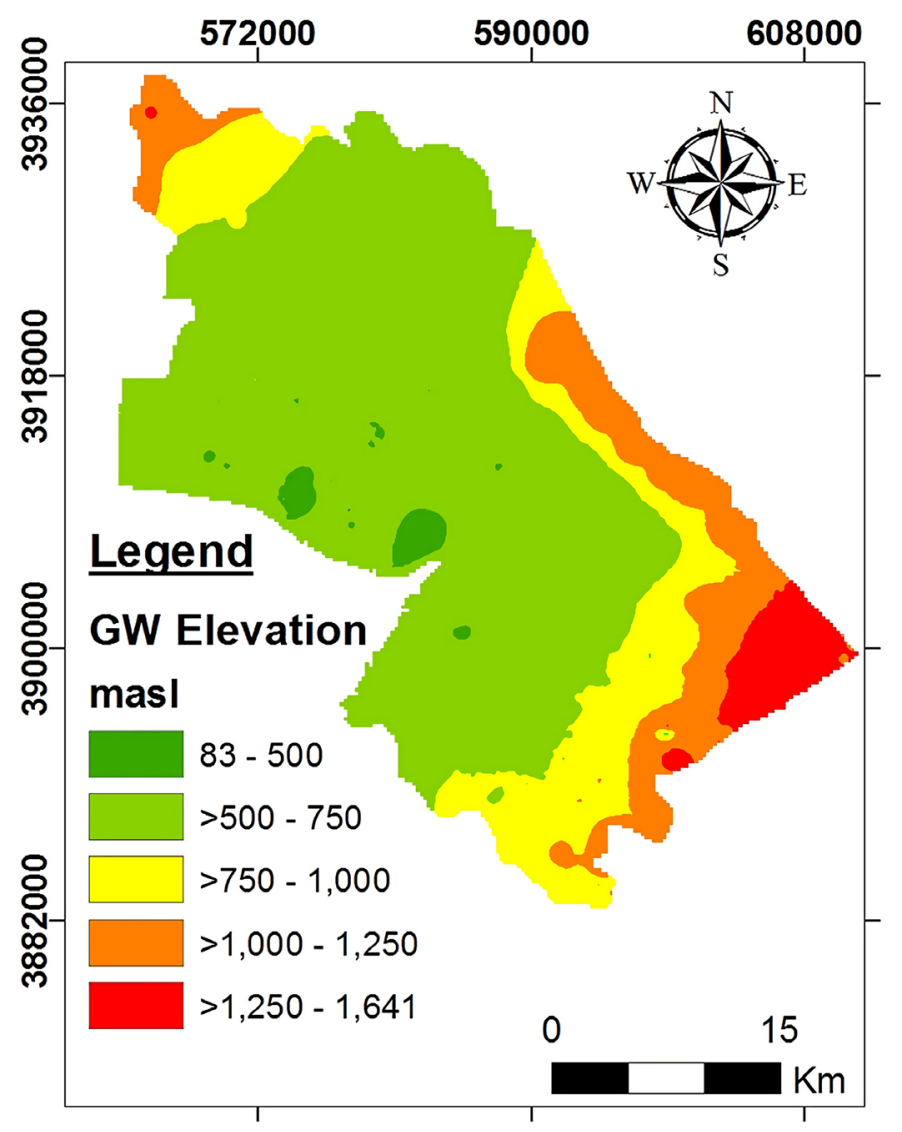

Figure 4. Groundwater head elevation. 


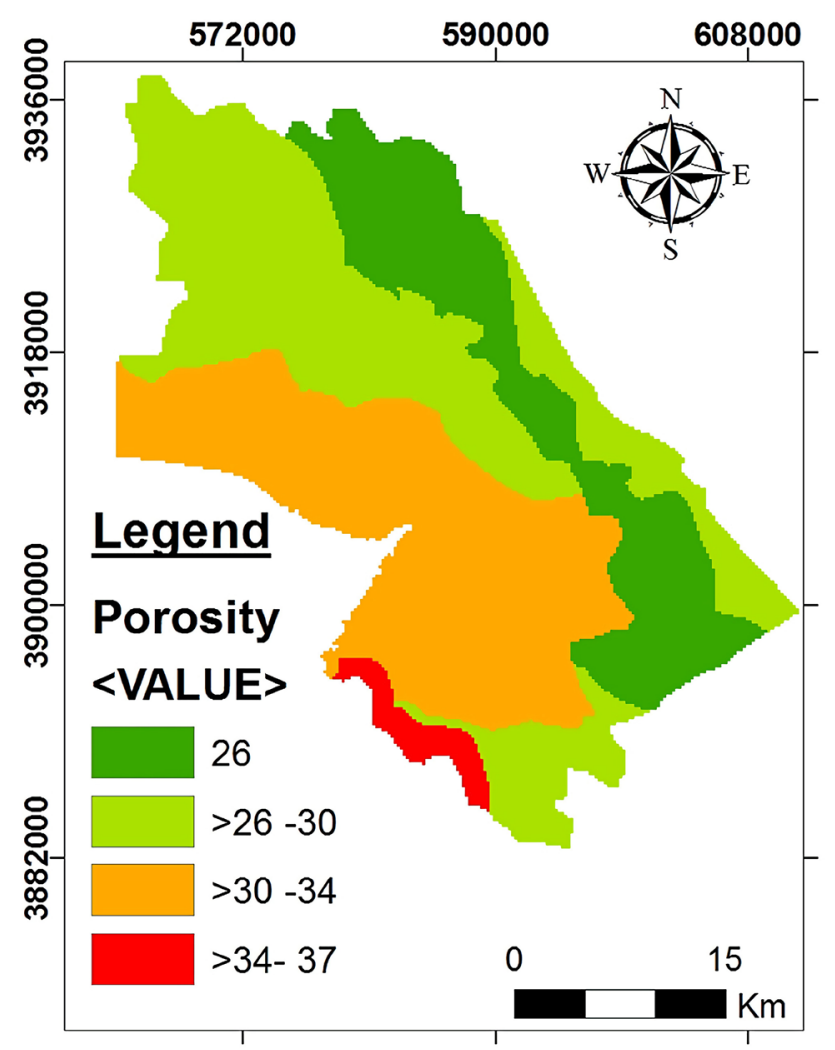

Figure 5. Effective porosity (\%).

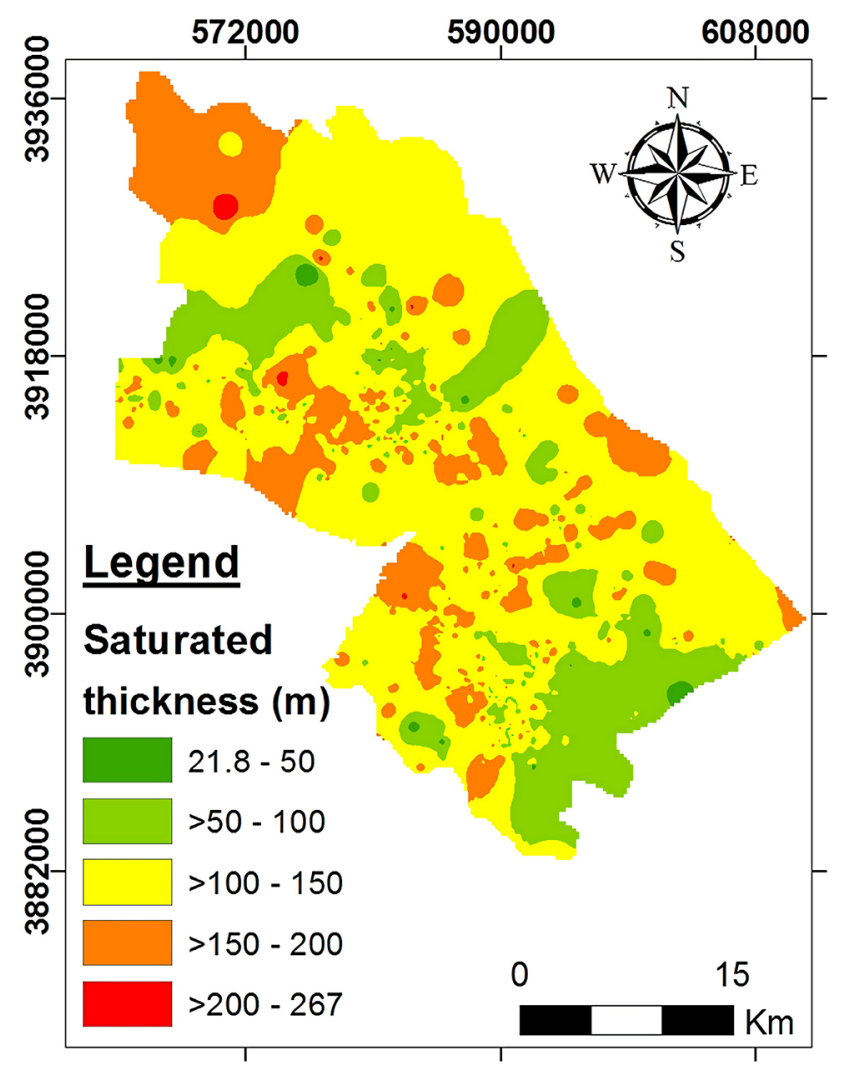

Figure 6. Saturated thickness of geological formation. 


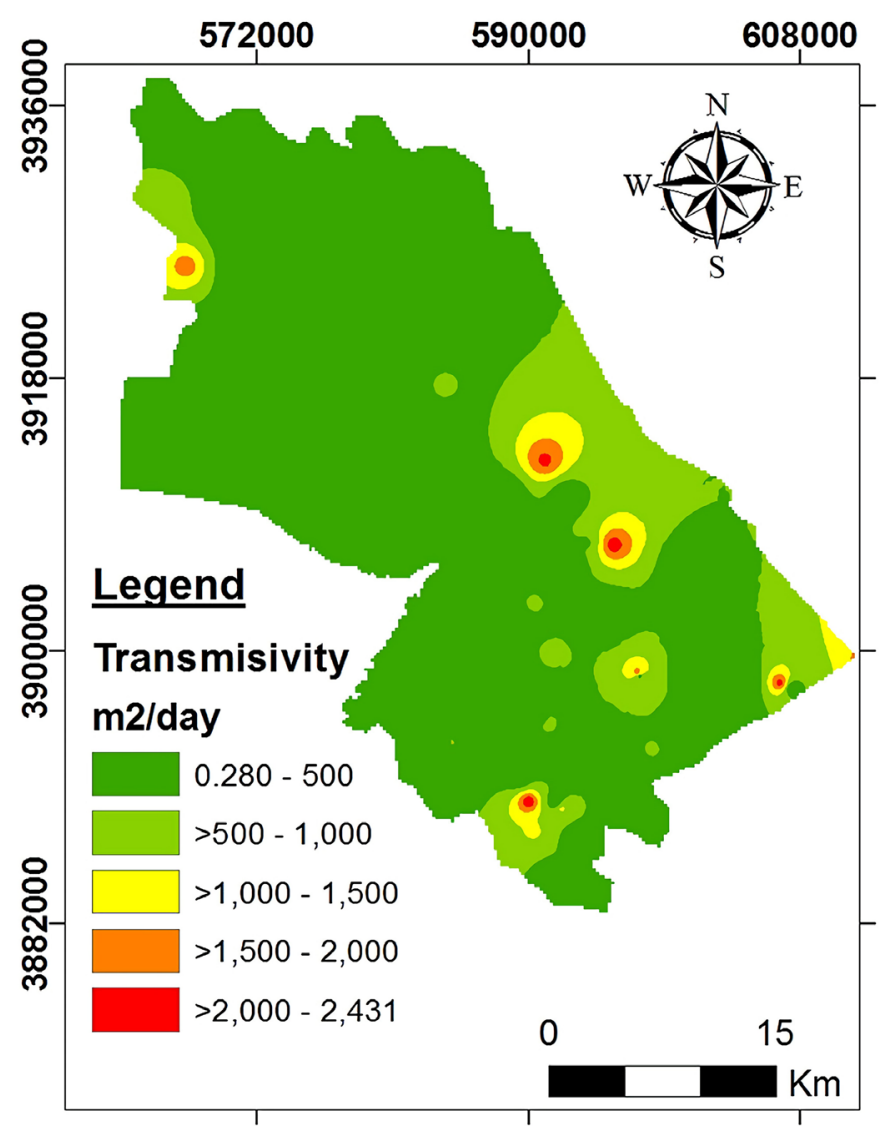

Figure 7. Aquifer transmissivity.

Seepage velocity direction and magnitude maps were constructed from Darcy Velocity command in the ArcMap software. The seepage velocity magnitude ranged (0 to 51) $\mathrm{m} / \mathrm{d}$, Figure 8 . In general, the flow direction is from the eastern part to the western part of the HSB, Figure 9. The factor controlling the flow direction in the HSB refer to the direction of dipping strata of geological formation, the high elevation head of groundwater in the eastern part and low transmissivity in the western part. The combination of the seepage velocity direction map and the groundwater head elevation map are represented in Figure 9. The seepage velocity direction is perpendicular to the groundwater potential line which is confirming the direction of flow toward the lower head elevation of groundwater. In addition, Figure 10 represent the combination of the seepage velocity magnitude and direction maps, the flow direction starts from the higher velocity magnitude (Eastern part) toward the lower velocity magnitude (Western part).

\section{Conclusions}

Hydrogeologically, Halabja Saidsadiq basin has been considered as one of the most important basins in the Iraqi territory in terms of quantity and quality of groundwater. The water demand provided mainly from groundwater resources. Therefore, the study of groundwater flow velocity magnitude and direction is 


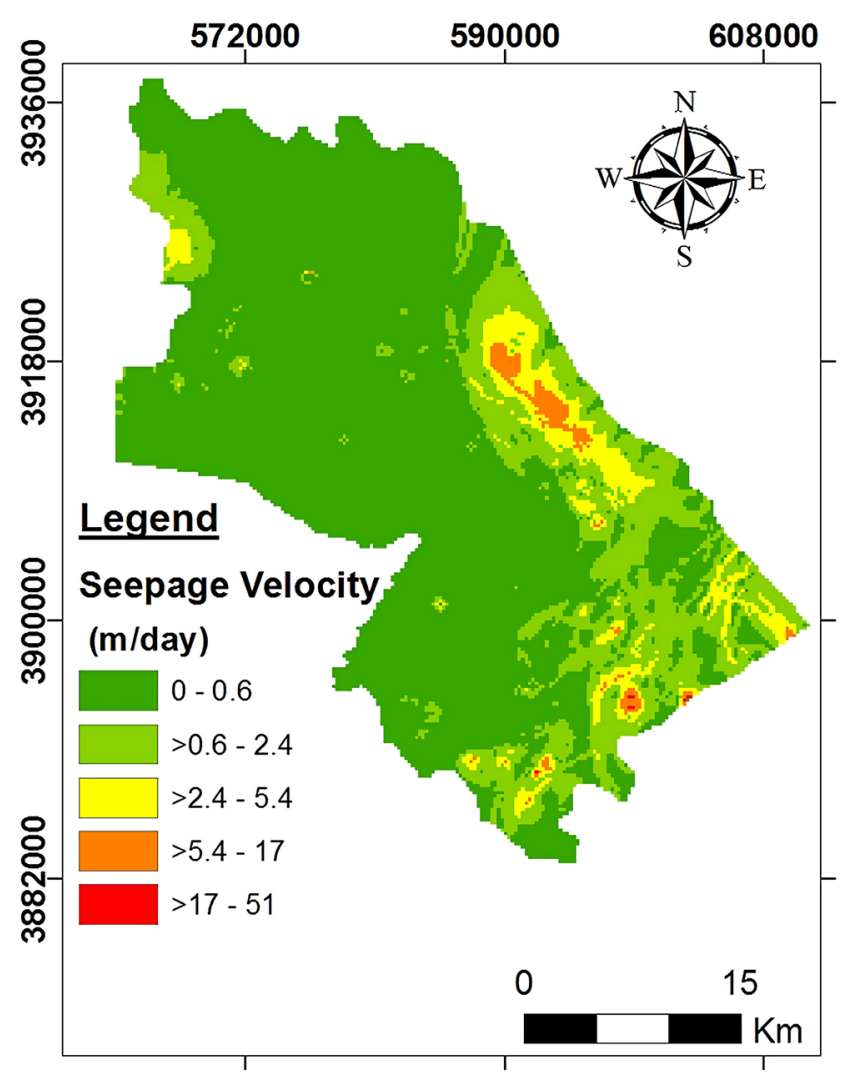

Figure 8. Seepage velocity magnitude of groundwater.

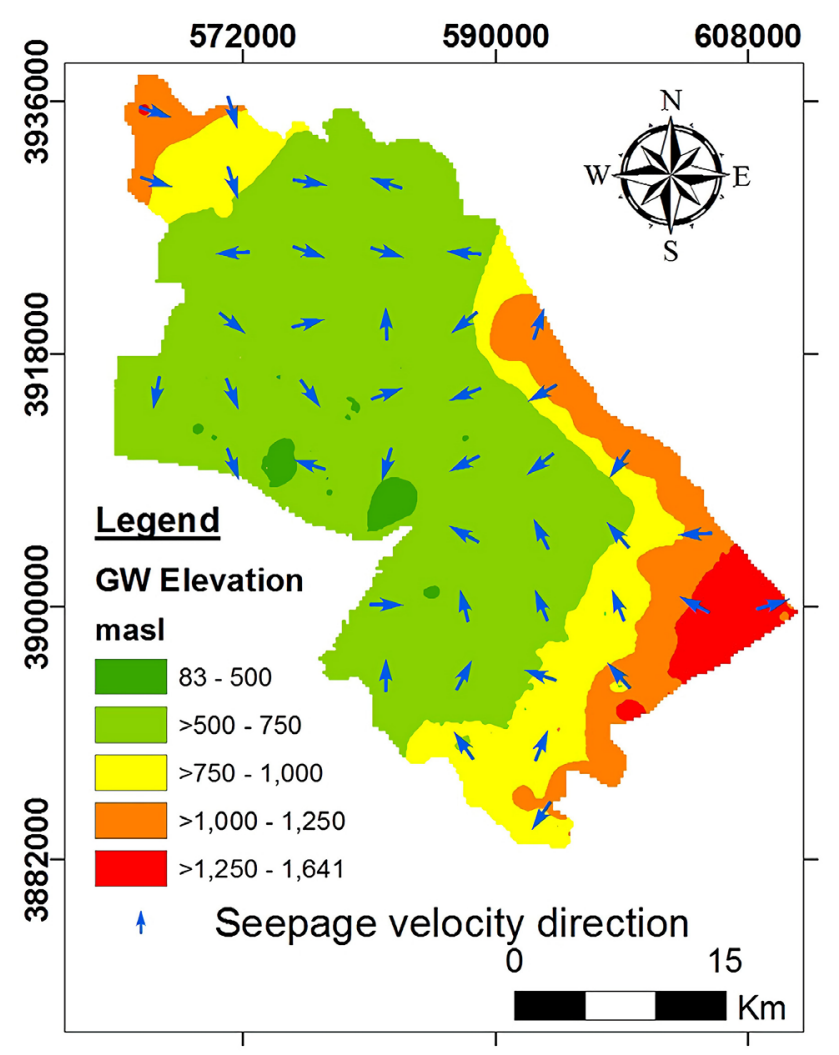

Figure 9. Direction and the groundwater head elevation. 


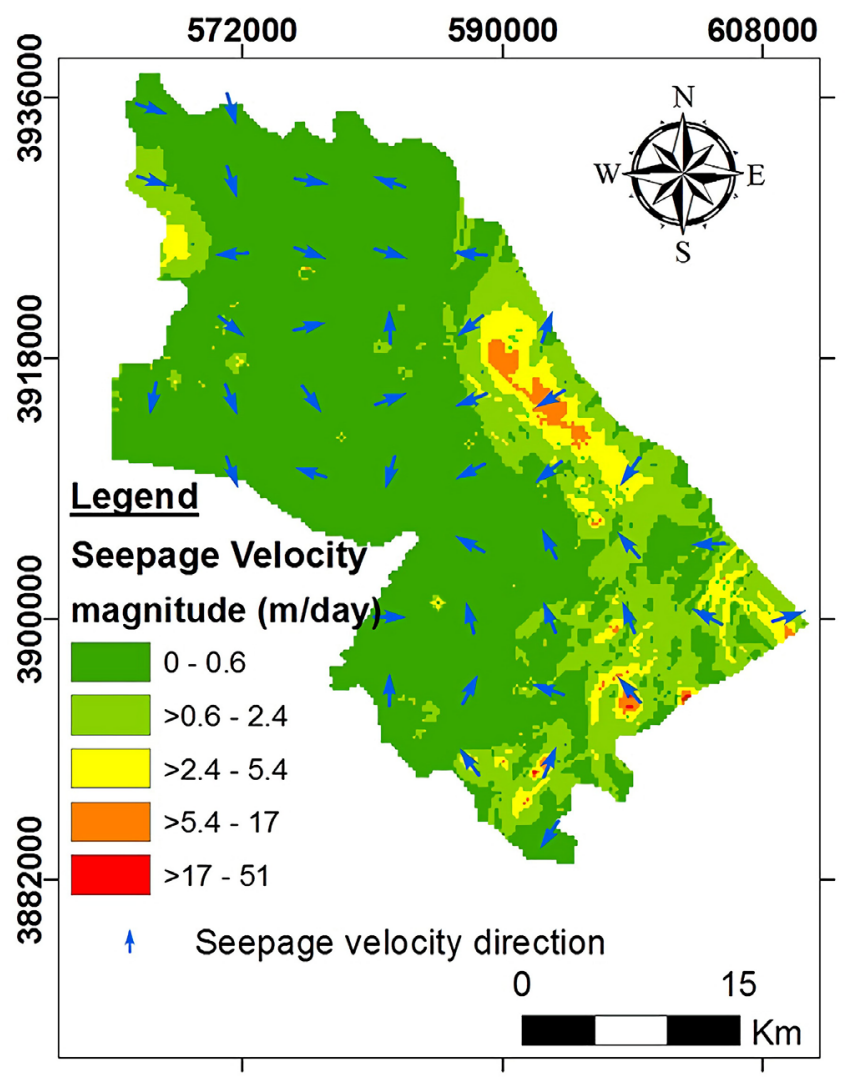

Figure 10. Seepage velocity magnitude and direction of the groundwater in the HSB.

of highly necessary, in order to introduce groundwater movement to prevent pollutant release gravitationally, and to observe enough groundwater quantity. The outcome designates that the groundwater flows from the eastern to the western part of the HSB, in general toward the Darbandikhan Lake in the southwestern part. This is related to the direction of dipping strata of the geological formation, transmissivity and the groundwater head elevation. The transmissivity in the area decreased toward the southwestern part and it ranges $(0.28-2431) \mathrm{m}^{2} / \mathrm{d}$, and in general, the water table is shallow in the southwestern part compared to the western part. The seepage velocity magnitude ranged from 0 to $51 \mathrm{~m} / \mathrm{d}$ because of different hydrogeological parameters of each groundwater aquifers namely: groundwater elevation head, effective porosity, saturated aquifer thickness and aquifer transmissivity.

This study applied Darcy velocity to estimate groundwater flow magnitude and direction based on observation borehole with pumping and several hydrogeological characteristics background. Consequently, the estimation of characterizing regional one-dimensional flow based on measurements from an observation borehole without pumping such as applying flux-based methods (e.g., dilution tests, Permeable Flux Meters) and in-hole velocity methods (e.g., Colloidal Borescope, Heat Pulse Flowmeter, Acoustic Doppler Flowmeter, In-Well Point Velocity Probe) is highly recommended for the future study in this specific study area. Fluxes or velocities inside the borehole must subsequently be transformed 
to regional Darcy flux in the aquifer, and then comparing the results to the results of current study.

\section{Conflicts of Interest}

The authors declare no conflicts of interest regarding the publication of this paper.

\section{References}

[1] Todd, D.K. and May, L.W. (2005) Groundwater Hydrology. John Wiley \& Sons, Hoboken.

[2] ESRI (Environmental Systems Research Institute) (2017) How Darcy Flow and Darcy Velocity Work. http://desktop.arcgis.com/en/arcmap/10.3/tools/spatial-analyst-toolbox/how-darcyf low-and-darcy-velocity-work.htm

[3] Osorno, T., Devlin, J.F. and Firdous, R. (2018) An In-Well Pointvelocity Probe for the Rapid Determination of Groundwatervelocity at the Centimeter-Scale. Journal of Hydrology, 557, 539-546. https://doi.org/10.1016/j.jhydrol.2017.12.033

[4] Devlin, J.F., Tsoflias, G., McGlashan, M. and Schillig, P. (2009) An Inexpensive Multilevel Array of Sensors for Direct Groundwater Velocity Measurement. Groundwater Monitoring and Remediation, 292, 73-77. https://doi.org/10.1111/j.1745-6592.2009.01233.x

[5] Abdullah, T.O., Ali, S.S., Al-Ansari, N.A. and Knutsson, S. (2015) Groundwater Vulnerability Mapping Using Lineament Density on Standard DRASTIC Model: Case Study in Halabja Saidsadiq Basin, Kurdistan Region, Iraq. Engineering, 7, 644-667. https://doi.org/10.4236/eng.2015.710057

[6] Abdullah, T.O., Ali, S.S. and Al-Ansari, N.A. (2016) Groundwater Assessment of Halabja Saidsadiq Basin, Kurdistan Region, NE of Iraq Using Vulnerability Mapping. Arabian Journal of Geosciences, 9, 223. https://doi.org/10.1007/s12517-015-2264-y

[7] Abdullah, T.O., Ali, S.S. and Al-Ansari, N.A. (2018) Possibility of Groundwater Pollution in Halabja Saidsadiq Hydrogeological Basin, Iraq Using Modified DRASTIC Model Based on AHP and Tritium Isotopes. Geosciences (MDPI), 8, 236. https://doi.org/10.3390/geosciences8070236

[8] Ali, S.S. (2007) Geology and Hydrogeology of Sharazoor-Piramagroon Basin in Sulaimani Area, Northeastern Iraq. Unpublished PhD Thesis, Faculty of Mining and Geology, University of Belgrade, Serbia, 317.

[9] Jassim, S.Z. and Goff, J.C. (2006) Geology of Iraq. In: Jassim, D.G., Ed., Geo Survey, Dolin, Prague and Moravian Museum, Brno, 340 p.

[10] Buday, T. and Jassim, S. (1987) The Regional Geology of Iraq: Tectonis, Magmatism, and Metamorphism. In: Kassab, I.I. and Abbas, M.J., Eds., Iraqi Geological Survey, Baghdad, 445. 